\title{
Effect of lucerne preservation method in lamb feeding
}

\author{
T Zelyazkov, T Naidenov, A Kirilov \\ Forage Institute, 5800 Pleven, Bulgaria
}

Under our climatic conditions a considerable part of green forage is stored for winter feeding of animals. Therefore it is very important to choose the most efficient method of lucerne preservation and utilization.

The objective of this study was to compare 10 methods of green lucerne preservation for lamb fattening : silage without additive - control, and with Acidol 50, Pentasil 80 or formic acid ; 2 haylages with dry matter (DM) about $40 \%$ without and with formic acid, haylage without additive with DM $56 \%$, field dried hay and barn dried hay ; and dehydrated meal. All additives were applied at a rate of $6 \mathrm{l} / \mathrm{t}$.

The study was carried out with lucerne variety Dunavka second regrowth, harvested at the stage of early flowering with a content of $22 \%$ crude protein and $28 \%$ crude fibre on a DM basis. Productive effect was determined in a trial on 140 male lambs with an average live weight of $35 \mathrm{~kg}$ of the Danube fine wool race, divided by analogs in 10 groups. Lamb ration consisted of equal parts $(50: 50)$ by DM of maize mash and lucerne forage from the respective treatment. The animals were fed ad libitum. The trial continued 56 days.
When DM increased, organic acid content in silage decreased. The additives improved fermentation process and decreased organic acid content in silage. Formic acid inhibited more strongly than Pentasil 80 and Acidol 50 the production of organic acids and ammonia nitrogen in silage. Dehydration increased the DM intake (DMI) by $29 \%$ and lamb gain by $68 \%$, and decreased forage consumption per $\mathrm{kg}$ gain by $23 \%$, compared to control. The additives Acidol 50, Pentasil 80 and formic acid increased silage intake by $5.5,7.3$ and $6.4 \%$, lamb gain by 15,26 , and $28 \%$, and decreased forage consumption per $\mathrm{kg}$ gain by $8.3,16.5$ and 16.8 respectively, compared to control. Lucerne preliminary drying increased the intake of haylage by $25 \%$ on the average, the gain by 41 to $57 \%$, and decreased forage consumption per kg gain by 12.8 to $20 \%$, compared to control. The haylage with higher DM content gave a better effect.

The haylage with $39.3 \%$ DM equalled in effect the field dried hay, and the haylage with $55.7 \%$ DM equalled the barn dried hay, but the hays and haylage were inferior to dehydrated lucerne.

\begin{tabular}{|c|c|c|c|c|c|c|c|c|c|}
\hline \multirow[t]{2}{*}{$\begin{array}{l}\text { Method of } \\
\text { preservation }\end{array}$} & \multirow[t]{2}{*}{$\begin{array}{l}\text { DM } \\
\%\end{array}$} & \multirow[t]{2}{*}{$\mathrm{pH}$} & \multicolumn{3}{|c|}{$\begin{array}{l}\text { Organic acids } \\
\% \text { dry matter }\end{array}$} & \multirow[t]{2}{*}{$\begin{array}{l}\mathrm{NH}_{3}-\mathrm{N} \\
\% \text { total }\end{array}$} & \multirow[t]{2}{*}{$\begin{array}{l}\text { Gain } \\
\text { g/day }\end{array}$} & \multirow[t]{2}{*}{$\begin{array}{c}\text { DMl } \\
\mathrm{kg} / \text { day/head }\end{array}$} & \multirow[t]{2}{*}{$\begin{array}{c}\mathrm{DM} \\
\mathrm{kg} / \mathrm{kg} \text { gain }\end{array}$} \\
\hline & & & Lact & Acet & But & & & & \\
\hline Silage - Control & 19.8 & 5.81 & 1.7 & 6.2 & 8.4 & 25.6 & 188 & 1.09 & 5.80 \\
\hline Silage $+0.6 \% \mathrm{~A}$ & 21.5 & 4.88 & 5.2 & 7.0 & 3.2 & 14.4 & 216 & 1.15 & 5.32 \\
\hline Silage $+0.6 \% \mathrm{P}$ & 21.1 & 4.59 & 4.0 & 3.1 & 2.6 & 9.2 & 236 & 1.17 & 4.96 \\
\hline Silage $+0.6 \% \mathrm{~F}$ & 21.3 & 4.27 & 5.4 & 6.2 & 0.0 & 6.4 & 240 & 1.16 & 4.83 \\
\hline Haylage - & 39.3 & 4.56 & 9.2 & 3.4 & 0.0 & 6.4 & 265 & 1.34 & 5.06 \\
\hline Haylage + $0.6 \mathrm{~F}$ & 40.8 & 4.51 & 7.6 & 3.5 & 0.0 & 4.3 & 295 & 1.37 & 4.64 \\
\hline Haylage & 55.7 & 5.00 & 7.0 & 1.8 & 0.0 & 5.2 & 285 & 1.36 & 4.77 \\
\hline Hay, field dried & 82.9 & - & - & - & - & - & 264 & 1.35 & 5.11 \\
\hline Hay, barn dried & 83.5 & - & - & - & - & - & 281 & 1.36 & 4.84 \\
\hline Dehydrated, meal & 88.2 & - & - & - & - & - & 316 & 1.41 & 4.46 \\
\hline
\end{tabular}

